\title{
Cultural Confidence and the Construction of College Students' Socialist Core Values
}

\author{
Yuexin Liu \\ School of Marxism \\ Wuhan University of Science and Technology \\ Huibei, China \\ 2625081159@qq.com
}

\begin{abstract}
From the perspective of cultural self-confidence consciousness, the cultivation of the college students' socialist core values is deeply analyzed, and the relationship between all parties that affect the formation of college students' core values has been combed, therefore, the way for the exploration of the path has been cleared. Through questionnaires, the status quo and problems of the socialist core values in the social groups of college students arise. Therefore, it is an important and urgent task to improve college students' awareness of cultural selfconfidence and strengthen the education of the core values of them.
\end{abstract}

\section{Keywords-Culture; Socialist core values; Universities}

I. ACCURATELY GRASP THE SCIENTIFIC CONNOTATION OF CULTURAL SELF-CONFIDENCE AND FULLY EXPOUND THE OBJECTIVE CONTENT OF SOCIALIST CORE VALUES

\section{A. Cultural self-confidence is original from self-confidence of cultural content}

1) Culture has a rich material form and is an objective carrier of socialist core values

Culture is material foundations for people to transform nature, all things with material and spiritual imprints are culture, culture, like human beings, depends on external existence world. Cultural contents are huge, if culture is compared to a concentric circle, then the outer layer represents the carrier of material culture, or reflects individual behavior and social behavior, the outer layer changes with society development. The inner layer represents the national economy, national character, and other spiritual factors, the more inner the layer is, the more stable spiritual factor is , and the stable cultural values is in the core place. Our country is of 2,000year-old feudal civilization, the dynasty has continue changed but maintained its consistency with the social system because of its vitality of cultural values. Therefore, we must establish strong cultural values, strong cultural awareness and cultural self-confidence. The practice of socialist core values is the need of building a powerful cultural country, and the construction of a powerful cultural country is an integral part of constructing a socialism with Chinese characteristics, because the cultivation of socialist core values must be carried out in the construction of a powerful cultural country and must be examined based on culture self-consciousness and cultural self-confidence [1].

2) Culture has a standardized institutional form and is the basic guarantee for cultivating and practicing socialist core values.

Adhering to the socialist system is the basic guarantee for cultivating and practicing socialist core values. If the values of an era lack a system, it is like the plants without sunshine, if we want to develop the influence of socialist core values, we must adhere to socialist system of Chinese characteristics, the socialist market economy system is an important part of socialism with Chinese characteristics, the market path of the socialist market economic system have brought us opportunities and challenges, facing with the pluralistic and varied ideological characteristics of the cultural field under the social new environmental market economy, we need to strengthen the concept of the core values of socialism, enhance the influence of the mainstream to socialist core values and improve the cultural soft power. Socialist core values has adapted to the trends of current time and the environment of current great changes, we must maintain values through the system as the guideline and foundation and take strong system as a guarantee to foster and practice socialist core values.

$B$. The relationship between socialist core values and cultural self-confidence

1) The cultivation of socialist core values fully reflects Chinese cultural self-confidence

The socialist core values system determines the development of socialism with Chinese characteristics, and puts forward three initiatives that shape the spirit of the times. The three initiatives logically penetrate every aspect of the socialist core values system and are rooted in the soil of China to highlight Chinese temperament, the three initiatives fully demonstrates the Chinese Communist Party's institutional selfconfidence and cultural confidence in the country's development.

2018 International Seminar on Education Research and Social Science (ISERSS2018) 
2) Giving full play to the value function of culture is the spiritual driving force for cultivating the core values of socialism

Values are the core of culture, culture is the carrier of value, the cultivation and practice of socialist core values cannot be separated from the cultural identity, the socialist core values follow the basic principles of Marxism, and also inherit the essence of Chinese traditional culture[2]. Only deep the self-identity of the country's culture, treating the traditional culture with a confident attitude, take its essence and abandon its dross for foreign culture can you provide spiritual motivation for the core socialist values.

3) Cultivating and practicing socialist core values helps to enhance people's cultural self-confidence

The socialist core values are a manifestation of cultural soft power, and the socialist core values have a profound influence on people's spiritual motivation. Without socialist core values, one culture cannot be strong. In the multipolarization of economic globalization, various ideas are mutual alter nation. It is the Chinese people's pursuit of value that strengthens the core socialist values and lead the social trend of thought, which is conducive to consolidating China's common ideal of socialism, enhance the soft power of Chinese culture, enhance the cultural awareness and cultural selfconfidence of the nation, promote Chinese culture better for the world and walking in the forefront of the world[3].

\section{THE CURRENT STATUS OF THE CULTIVATION OF SOCIALIST CORE VALUES OF CONTEMPORARY COLLEGE STUDENTS}

\section{A. The status of cultivation methods}

1) Strengthen theoretical research and improve educational concepts

Study the college students' ideological characteristics, pursue psychological and moral sentiments. The difference in the state of thinking of each college student determines the difference in the way they view things and the difference between the three outlooks on life. Only the study of college students themselves, can it make college students better implement the socialist core values and integrate the college students into the socialist core values.

2) Renew education methods and innovative teaching quality

The modernization of education must face modernization, the world and the future. For the cultivation of college students' socialist core values, teachers can use the content of socialist core values as a propaganda film. They can also hold essay competitions outside class to motivate college students to better promote the socialist core values.

Make full use of network resources. Nowadays, in the popularity of the Internet, the Internet has become an indispensable platform for college students to acquire information and knowledge. For example, the online carrier for university network teaching must be continuously updated, and content on more socialist core values should be updated.

\section{3) Optimize the educational environment}

The cultivation of the socialist core values of college students must take into account the general environment of society, and also consider the influence of these major environments on the core values of socialism. The society's money worship and hedonism are not always buzzing around the students. We have eradicated malignance of the society. In this case, we must promote the socialist core values to students, make the social environment more harmonious, and enhance the effect of undergraduate cultivation of socialist core values.

\section{B. The Status of Cultivation Results}

The process of cultivating the socialist core values for college students is based on practice. By investigating the establishment of socialist core values among college students, basic data are obtained and analyzed.

The significance of the socialist core values is studied, and 80 percent are very significant, and 15 percent are considered meaningless, and 3 percent are considered meaningless.

With respect to the acceptance of socialist core values, 50 percent of college students can listen to their lectures and take notes actively. 15 percent of college students are forced to attend classes, and 8 percent of college students are not interested, playing mobile phones in the class and other behaviors, $3 \%$ of college students skip classes to do something else.

Regarding the importance of practicing socialist core values, 80 percent of college students believe that the practice of socialist core values is beneficial to the value of life, However 13 percent of college students believe that the practice of socialist core values is optional. 3 percent of three college students agree that it is meaningless to practice socialist core values.

According to the above investigation and analysis, the socialist core values have thoroughly analyzed the status quo and problems existing in the social groups of college students, and put forward solutions to the problems, and improve and perfect the issue of upholding the socialist core values. Socialist core values were accepted by more college students, which has achieved the expected results.

\section{PROBLEMS IN THE CULTIVATION OF CONTEMPORARY SOCIALIST CORE VALUES}

\section{A. The status quo of problems}

1) The cultivation of socialist core values are very weak

With the introduction of the core values of socialism, colleges must cultivate the socialist core values and strengthen the cultivation of awareness,avoid passive education processes, go deep into the environment of college students and ensure individuals and families can participate in. University is the cradle of flying dreams. The characteristics of college students are distinctive. In the process of nurturing colleges, we must consider the students' thinking for the students' actual conditions, get the approval of college students, and improve the hard education model. 
2) The measures of socialist core values are incomplete In the process of nurturing socialist core values, there must be complete measures in addition to complete plans. At present, the socialist core values in our colleges need to be strengthened. Therefore, we must combine theory with practice to conclude that the system of socialist core values is incomplete, and actively promote the cultivation of socialist core values. In the process of cultivation, we must guide college students to have the ability to discriminate, guide the understanding of the socialist concept of honor and disgrace, and guide college students to establish the correct stage of life. College is the main position to foster college students. The school must innovate teaching objectives and provide a platform for college students to receive knowledge education, schools should be linked with the family, and they work together to do a good job of fostering socialist core values.

\section{B. Analysis of the causes of problems in the cultivation of current socialist core values}

\section{1) Individual characteristics of college students}

With the development of economy and society, our way of life has not only changed, but also the way of thinking has changed. College students are the most receptive group for information, and they are also susceptible to some wrong thoughts. The diversified society has enabled college students to accept different ideas and make students realize the polarization of socialist core values. For college students who have established socialist core values, it is not easy to fall into the wrong direction, For college students who are establishing core socialist values, they are more likely to be unable to distinguish between them, They are vulnerable to wrong thoughts and bad social influence. Faced with such a situation, it is necessary to guide college students in how to distinguish between them and ensure that they establishes a positive and healthy socialist core values and indicate the path of life.

\section{2) Influence of social development status}

College students are in the period of growth, they are still not aware of the state of the society, and have insufficient understanding of the complexity of the society. Therefore, in the cultivation of socialist core values of college students, college students are hindered by the socialist core values. Society is a relatively complex one, and it must have a profound understanding to solve the problems that arise. Due to the lack of social experience for contemporary college students, the ugly phenomenon in society cannot be discerned, and values may be impetuous. After the Internet's life entered, all kinds of values appeared, and distorted notes appeared in the values of the entire society. In particular, contemporary college students lack life experience and the ability to distinguish between right and wrong, which has a negative impact for them on the cultivation of socialist core values.

\section{3) Analysis of the status quo of education methods}

The cultivation of socialist core values and the effectiveness of college education have been crucial. In recent years, colleges and universities have achieved a series of achievements in the education of socialist core values. However, the key of problems is that the inevitable social practice is the most important part for the cultivation of core socialist values of college students. The practice of social practice has brought some experience, but some important issues have not attracted attention. College educates college students to strengthen the cultivation of socialist core values, and carry out social practice activities, which only pays attention to the participation of students in the social practice and enthusiasm, and did not pay enough attention to the social construction activities of the ideological construction connotation. This phenomenon can be seen everywhere in colleges, which influences the effect of education on college students' socialist core values. The education of the socialist core values of college students has become a problem worthy of attention in colleges[4]. Colleges should strengthen the effectiveness of the training of socialist core values, must strengthen the ideological construction of college students' socialist core values, and should pay attention to the forms, But we must pay more attention to its connotation and strengthen the healthy and upward development of the mainstream[4].

\section{ACTIVELY EXPLORE WAYS OF NURTURING CULTURAL SELF-CONFIDENCE, AND PROMOTE THE CULTIVATION OF COLLEGE STUDENTS' SOCIALIST CORE VALUES}

\section{A. The socialist core values must implement the ideological and political classroom in colleges and universities}

It is mainly to strengthen the study of theoretical education, Profoundly start with theories, correct the students' ideological motives, strengthen political awareness, strengthen the moral consciousness of college students, and establish a life outlook, values, and society concept that strengthen the teaching classroom of ideological and political classes and improve innovation. In the education of socialist core values, college students should play a good role in the main channels of the classroom and strengthen the teaching of ideological and political courses. Whether the teachers and teaching facilities must use hardware. The most important thing is to innovate in teaching. With the extensive use of the Internet,multimedia teaching is adopted, which makes students can speak in the form of ppt and builds a more intense interest in the ideological classroom. Meanwhile we need play the role of elective classroom, promote the Chinese excellent culture by a wide variety of elective courses, and strengthen the recognition of college students in the education of socialist core values. Secondly, We must innovate more forms to allow socialist core values to play a role in other classrooms[5].

\section{$B$. Strengthen understanding of the mainstream in the content and form of the ideological classroom}

Integrate socialist core values into the content of teaching materials makes different teaching materials and socialist core values combined to give play to the leading role of socialist core values[5].For example, in the Outline of Modern History, we must use historical knowledge to strengthen our understanding of the core values of socialism. In the ideological and moral cultivation and basic legal teaching, it focuses on the understanding of social moral consciousness, social public moral consciousness, and faith awareness. In addition to educating the students in the teaching materials, the educators carry out the practice of the second class and construct a practical teaching mechanism with rich content and flexibility. 


\section{The core value of socialism leads the campus culture and cultivates cultural confidence of students}

\section{1) Establish a value orientation for college students}

Faced with the impact of complex culture, it is very important for college students to cultivate the value orientation. Campus is the main position of cultural inheritance and cultural innovation. It is necessary to insist on leading the campus culture with socialist core values. Colleges should integrate socialist core values into the thinking of college students. In order to better establish values, college students are required to establish correct value orientation. Under the conditions of economic globalization and frequent information exchange, the values of Chinese college students may be plagued by shocks and value choices. This requires that college students establish a correct value orientation.

2) Socialist core values lead campus life and enhance the charm of campus culture

The socialist core values are not empty talks. We need our contemporary college students to practice in practice, For the majority of teachers and students living in colleges, the campus culture is student-centered, and the social life values lead the campus cultural life. Through a variety of social groups, holding colorful activities, which embody the core socialist values and the characteristics of the times, and make the essence of campus culture go back to ancient times. Guide college students to read classics, cultivate innovative abilities, and strengthen the dissemination of campus activities. College students in practice reflect the socialist core values and create a strong campus atmosphere. It is utmost importance for building a first-rate campus to cultivate and practice the socialist core values in. The socialist core values lead to the campus culture and strengthens the recognition of the main body. Colleges should create a campus culture atmosphere, hold various academic lectures, and conduct academic exchanges. Open up students' vision and enlighten their thinking.

\section{3) An effective way to improve the confidence of campus} culture

Enhance the construction of campus hardware. These hardware construction facilities include cafeterias, teaching departments, dormitory rooms, laboratories, etc. That all are necessary places for college students in the school to carry out the protection smoothly. Under a good environment, college students can be more comfortable to study and live. The main body of the campus environment is college students. A good environment can make students feel happy, enhance their motivation, and cultivate their sentiments.[6]
There are many contents for strengthening the construction of campus software culture, such as school spirit, school motto, dormitory system, class system, school rules and regulations, school of school songs, and the relationship between teachers and students. These are the components of campus soft culture. The fine school spirit is to build a foundation for a positive campus, build a fine school spirit, and to create an inspiring cultural atmosphere. At the same time, it is necessary to establish a group of noble teachers and responsibility teaches students, which will better guide the healthy development of students.[6]

\section{CONCLUSION}

College students are the successors of socialism and the backbone of the country. With the infiltration of social pluralism, many college students' values are under attack. Money worship and hedonism are raging around them. The students' thinking and psyche are not yet fully matured, and they are easily influenced in the process of forming values. It is an important and urgent task to improve college students' awareness of cultural self-confidence and strengthen the education of the core values of them.

This paper analyzes under the cultural self-confidence consciousness the fostering and cultivation of college students' socialist core values. The cultivation of students' core values is one of the important contents of ideological and political education. The ideological and political education is a longterm and arduous task. We should, on the basis of raising cultural self-confidence, give full play to the work of ideological and political education from the perspective of college students, be suitable for the development of the times, and constantly advance with the times.

\section{REFERENCE}

[1] Huang Yuxia. On contemporary college students' cultural a wareness and cultural self-confidence [J]. Chinese Times, 2015 (4). (In Chinese)

[2] Ouyang Junxi, Cui Chunxue. The Cultivation of Chinese Traditional Culture and Socialist Core Values[J]. Shandong Social Sciences, 2013(3):11-15.(In Chinese)

[3] Liang Xiuwen. The cultural Cultural Self-confidence and Socialist Core Values [N]. Academic Journal of Zhongzhou, 2016(11):80-86. (In Chinese)

[4] Bo Lu. On the Way of Integrating Socialist Core Values into College Students' Ideological and Political Education [J], Reform and openness, 2017 (12):102-103. (In Chinese)

[5] Sun Jianqing. Research on contemporary Chinese college students' core values education [D]. Shandong University, 2014.74-76. (In Chinese)

[6] Jiao Lian zhi, Huang Yiling. Cultivation of socialist core values from the perspective of cultural self-confidence [J]. Educational Exploration, 2016 (8):87-90. (In Chinese) 